\title{
Estimation of Femoral Head Bone Mineral Density in Hip Fractures of the Elderly
}

\author{
Yaşlı Kalça Çevresi Kırıklarda Femur Başı Kemik Mineral Yoğunluğunun Değerlendirilmesi
}

\section{Bilal Koyuncu ${ }^{1}$, Murat Songürr ${ }^{2}$, Selçuk Keser ${ }^{2}$, Ercan Şahin ${ }^{2}$, Selda Sarıkaya² ${ }^{2}$ Ahmet Bayar ${ }^{2}$, Onur KaymakçI ${ }^{3}$}

${ }^{1}$ Ministry of health, Manisa Education and Training Hospital, Dept. of Orthopaedics and Traumatology, Manisa, Turkey

${ }^{2}$ Bulent Ecevit University, Faculty of Medicine, Dept. of Orthopaedics and Tramatology, Zonguldak, Turkey

${ }^{3}$ Ministry of Health, Muş State Hospital, Dept. of Orthopaedics and Traumatology, Muş, Turkey

\section{ABSTRACT}

Objective: It is usually challenging to decide which hip fractures should be fixed and which should be replaced to avoid fixation failure and revision. Therefore, it may be of benefit to evaluate the bone mineral density of the fixation point of the femoral head preoperatively. In this study we tried to investigate the relationship between the bone mineral density (BMD) of the fixation point of femoral head, which is the primary compressive trabeculation area, and other parts of the proximal femur evaluated routinely during Dual-Energy X-ray absorptiometry (DXA) measurements. Methods: Retrieved femoral heads of 29 patients during hemiarthroplasty for hip fracture were evaluated using DXA. These results were correlated with the DXA measurements of proximal femora of uninvolved hips of patients.

Results: Mean BMD values of retrieved femoral head primary compressive trabecular region (PC-BMD) values were $0.610 \pm 11\left(\mathrm{~g} / \mathrm{cm}^{2}\right)$. Although there were significant positive correlation of PC-BMD with neck, Ward's and total proximal femoral region as expected, highest correlation coefficient was calculated at femoral neck region. These results did not differ when patients were regrouped according to uninvolved side BMD values as osteoporotic and osteopenic. There were no difference in both sexes in this relationship between values of PC-BMD, neck BMD, Ward's BMD and total BMD.

Conclusion: As expected, a positive relationship was found between PC-BMD values and neck BMD, ward's BMD and total BMD values with neck BMD revealing the highest correlation. Preoperative bone mineral densitometric evaluation of the uninvolved hip, especially the neck region seems to be helpful to evaluate the densitometric status of femoral head to predict early failure when fixation was attempted.

Key Words: Osteoporosis, BMD, proximal femur fracture, hemiarthroplasty, internal fixation

\section{ÖZET}

Amaç: Kalça çevresi kırıklarda tespit veya kalça replasmanı kararı vermek bazen kolay olmayabilir. Tespit sonrası implant yetmezliği ihtimalini azaltmak adına femur başında tespit materyallerinin yerleştirildiği bölgelerin kemik mineral yoğunluğunun bilinmesi faydalı olabilir. Bu çalışmada rutin DEXA ölçümü ile ölçülemeyen femur başı primer kompresif trabekül bölgesinin kemik yoğunluğunu belirlemeyi ve proksimal femurun diğer bölgeleri ile olan ilişkisini belirlemeyi amaçladık.

Yöntemler: Kalça kırığı nedeniyle hemiartroplasti uygulanan 29 hastadan çıkarılan femur başlarının kemik mineral yoğunlukları DEXA yöntemi ile değerlendirildi. Elde edilen ölçümler hastanın sağlam olan diğer kalça DEXA değerleri ile karşılaştırıldı.

Bulgular: Ortalama femur başı primer kompresif trabekül bölgesine ait kemik mineral yoğunluğu (PK-KMY) $0.610 \pm 11\left(\mathrm{~g} / \mathrm{cm}^{2}\right)$ olarak belirlendi. Beklendiği üzere elde edilen KMD değerleri proksimal femurda rutin DEXA ölçümü ile değerlendirilen diğer bölgeler (boyun, Ward's ve toplam proksimal femur) ile uyum gözlenirken, en güçlü ilişki boyun bölgesi KMY yoğunlukları ile gözlendi. Kemik mineral yoğunluklarında cinsiyet açısından herhangi bir fark gözlenmedi.

Sonuç: Beklendiği üzere primer kompresif trabekül bölgesi kemik mineral yoğunluğu ile en kuvvetlisi boyun ile olmak üzere, Ward's ve toplam proksimal femur kemik mineral yoğunluğu arasında olumlu ilişki gözlendi. Ameliyat öncesi özellikle boyun bölgesi olmak üzere, sağlam kalçanın kemik mineral yoğunluğunun ölçülmesi tespit yapılması planlanan hastalarda erken mekanik yetmezliğin önlenmesi adına faydalı olabilir.

Anahtar Sözcükler: Osteoporoz, kemik mineral yoğunluğu, proksimal femur kırığı, hemiartroplasti, internal tespit

Geliş Tarihi: 15.01 .2015

Kabul Tarihi: 10.07.2015 


\section{INTRODUCTION}

Despite modern fixation devices, reoperation rate following femoral neck fractures is reported to be between $0.8 \%-35 \%$. Loss of fixation is one of the main reasons for reoperation after proximal femoral fractures (1). Although, mode of failure is multifactorial and failure of reduction and poor implant positioning are the main reasons for failure, there is a high correlation with osteoporosis and fixation failure in hip fractures (2). It was shown that femoral head bone mineral density and femoral neck diameter has direct influence on fixation strength with cannulated screw or sliding hip screw fixation (3). In biomechanical studies, a critical bone mineral density of 0.4 $\mathrm{g} / \mathrm{cm}^{3}$ with radiographic attenuation technique (RAT) was defined to ensure stable fixation. But this finding has not been validated clinically. Also a BMD range of $260-370 \mathrm{mg} / \mathrm{cm}^{3}$ calcium hydroxyapatite (CaHAp) at femoral head center was described as necessary to ensure stable fixation of hip fractures $(1,4)$.

Many radiological methods are available to predict the densitometric status of the proximal femur such as Dual energy X-ray absorptiometry (DXA) evaluation, quantitative $C T$, Singh index and other parameters. Despite recent advances, DXA still remains as a valuable tool for the evaluation of bone mineral status of proximal femur except femoral head. As the femoral head is covered anteriorly and posteriorly by acetabulum, it is not possible to evaluate the densitometric status of fixation or anchorage area by routine DXA. In this study we aimed to investigate the bone mineral densitometric status of primary compressive trabecular area of the femoral head from cadaveric femoral heads retrieved during hemiarthroplasty, which could not be investigated by routine DXA in vivo. We also aimed to define correlation between the densitometric relation of femoral head primary compressive trabecular area of retrieved femoral heads with uninvolved side proximal femur areas of same patient (Neck, Ward's, intertrochanteric, trochanteric and total proximal femur) using DXA measurements.

\section{MATERIALS AND METHOD}

In this study we evaluated bone mineral densities of twenty nine cadaveric femoral heads, retrieved during hip replacement surgery (hemiarthropasty) with the diagnosis of osteoporotic hip fracture. Previous surgery to contralateral hip, advanced coxarthrosis, pathological fractures, high energy trauma and femoral heads those were traumatized during removal were excluded from evaluation.

Bone mineral densities of unaffected hips of all patients were evaluated by DXA method preoperatively (Hologic QDR 4500W- Hologic Inc. Bedford, USA). Same device was used for evaluation of retrieved femoral heads. Subregional analysis method was used in the analysis of the retrieved femoral heads. Since femoral head size differs among individuals, a constant area couldn't be selected for evaluation of all heads. As the fixation devices used in hip fracture surgery use primary compressive trabeculation area for bony purchase, this region was defined as region of interest. Similarly, due to femoral head size variety, femoral head total values were not taken into consideration. By referencing Fovea centralis, all femoral heads were positioned at standard AP view and scanned (Figure 1). To ensure consistency and reliability, scans were made twice by the same technician. To assess the reproducibility of the analysis CV value was calculated as 0.98 by the following formula;

$$
C V \%=\frac{100 \sqrt{\frac{\sum_{i=1}^{i=n}\left(a_{i}-b_{i}\right)^{2}}{2 n}}}{\frac{\bar{a}+\bar{b}}{2}}
$$

$\mathrm{n}=$ number of the patient

$a, b$ = measurements of one specimen

$\bar{a}, \bar{b}=$ mean values of first and second measurements respectively
Figure 1. Figure representing primary compressive area and region of interest (ROI) of bone mineral density measurement (a) and border of resected bone (b).

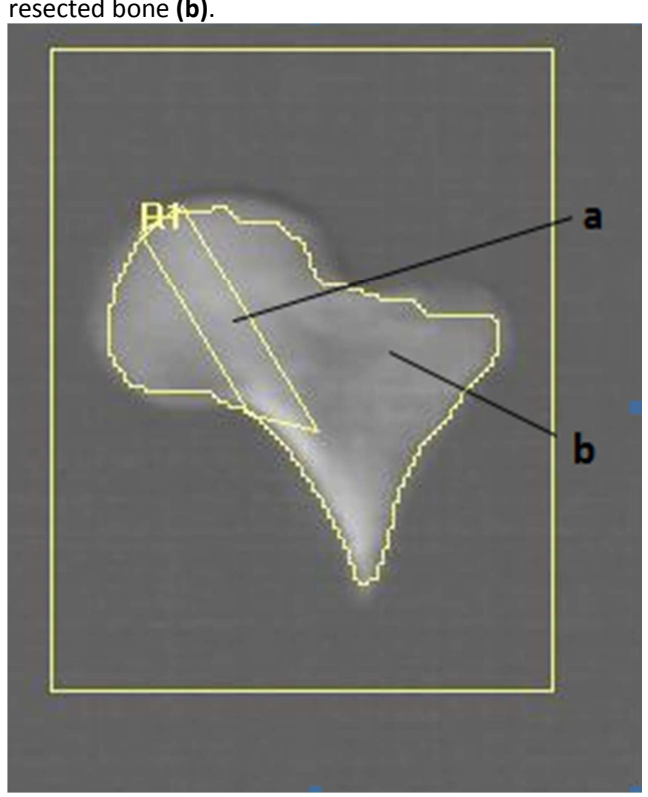

Statistical Analysis

Statistical analyses were made by using SPSS (ver. 13.0) software. Kolmogorov-Smirnov test was used to evaluate distribution of numeric variables to normal. Linear relations between two variables were evaluated by Pearson correlation analysis. Results were interpreted in $95 \%$ confidence interval and $p$ value less than 0.05 was accepted as significant.

\section{RESULTS}

Male to female ratio was $0.61(11 / 18)$. Fracture was at femoral neck in twelve, cervicotrochanteric area in eleven, intertrochanteric in five and subtrochanteric in one patient. Mean age and body mass indices of the patients are $78.7 \pm 10.0$ and $27.0 \pm 4.3$ respectively. Bone mineral density measurements and T-score values of uninvolved hip and bone mineral density of the primary compressive area were summarized at Table 1.

DXA results of uninvolved hip also were categorized as osteopenic or osteoporotic, according to T-scores of regions (neck, Ward's, intertrochanteric, trochanteric and total). This revealed $53.1 \%$ of measurements were calculated as osteoporotic. BMD measurements according to diagnosis were also summarized in Table 2.

There was a positive and strong correlation between bone mineral density values of primary compressive trabecular area (PC-BMD) of retrieved femoral heads and bone mineral density values of all areas of proximal femur (neck $B M D$, ward's BMD, total BMD) as expected $(r=0.85, p<0.001, r=0.74, p<0.001$ and $r=0.74, p<0.001$ respectively). Correlation coefficients of PC-BMD according to areas were listed at Table 3 . The highest correlation coefficient was calculated at femoral neck region at both osteoporotic and osteopenic cases $(r=0.63(p=0.007)$ and $0.89(p<0.001)$ respectively. Also, the highest correlation coefficient was observed at femoral neck region at both male and female patients $(r=0.73(p=0.011)$ and $r=0.81 \quad(p<0.001)$ respectively). No relation between PC-BMD and other areas of proximal femur could be identified according to body mass index distribution.

Table 1. Mean BMD measurements and T-score values.

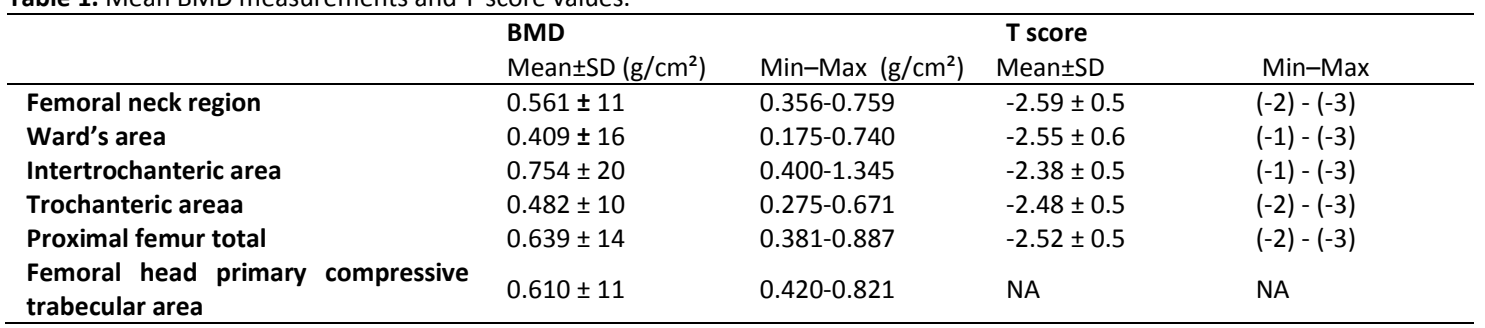

NA: not availa 
Table 2: BMD values according to diagnosis

\begin{tabular}{lllll} 
Table 2: BMD values according to diagnosis & \\
& $\begin{array}{l}\text { Femoral neck Fx. } \\
(\mathrm{n}=12) \text { Mean } \pm \text { SD }\end{array}$ & $\begin{array}{l}\text { Cervicotrochanteric Fx. } \\
(\mathrm{n}=11) \text { Mean } \pm \text { SD }\end{array}$ & $\begin{array}{l}\text { Intertrochanteric Fx. } \\
(\mathrm{n}=5) \text { Mean } \pm \text { SD }\end{array}$ & $\begin{array}{l}\text { Subtrochanteric Fx. } \\
(\mathrm{n}=1)\end{array}$ \\
\hline nBMD & $0.585 \pm 0,11$ & $0.534 \pm 0,11$ & $0.567 \pm 0,10$ & 0.553 \\
wBMD & $0.447 \pm 0,17$ & $0.368 \pm 0,17$ & $0.429 \pm 0,13$ & 0.302 \\
iBMD & $0.816 \pm 0,20$ & $0.643 \pm 0,18$ & $0.891 \pm 0,13$ & 0.556 \\
trBmD & $0.524 \pm 0,09$ & $0.419 \pm 0,10$ & $0.524 \pm 0,10$ & 0.464 \\
tBMD & $0.673 \pm 0,10$ & $0.569 \pm 0,14$ & $0.749 \pm 0,12$ & 0.462 \\
PC-BMD & $0.634 \pm 0,11$ & $0.571 \pm 0,11$ & $0.652 \pm 0,12$ & 0.546 \\
\hline
\end{tabular}

nBMD: Femoral neck area bone mineral density

WKMY: Ward's area bone mineral density

iKMY: Intertrochanteric area bone mineral density

trKMY: Trochanteric area bone mineral density

tKMY: Proximal femur total bone mineral density

PC-BMD: Primary compressive trabecular area bone mineral density of retrieved femoral heads

Table 3. Correlation coefficients of PC- BMD with BMD values of proximal femoral areas

\begin{tabular}{lll}
\hline & $\mathrm{r}$ & $\mathrm{p}$ \\
\hline nBMD & $\mathbf{0 . 8 5}$ & $<0.001$ \\
wBMD & 0.74 & $<0.001$ \\
trBMD & 0.59 & 0.001 \\
iBMD & 0.56 & 0.002 \\
tBMD & 0.74 & $<0.001$ \\
\hline
\end{tabular}

\section{DISCUSSION}

There are several papers reporting the relationship between low bone mineral density with fixation failure. Sjostedt et al. demonstrated unacceptably high mechanical failure at fixation of osteoporotic cadaveric femoral necks with BMD less than $0.4 \mathrm{~g} / \mathrm{cm}^{2}$ (2). Hedström reported 25 percent nonunion rate at geriatric femoral neck fractures. Mean neck BMD values of nonunion cases was reported as $0.600 \mathrm{~g} / \mathrm{cm}^{2}$ with mean T-score of 3.1. Low BMD was also reported to be a risk factor for nonunion of femoral neck fractures (5). Jenny et al. reported a high BMD with large femoral head was associated with better fixation and better cut-out resistance at femoral head (6). Also there are reports of increased biomechanical strength of fixation, by cement augmentation into fixation area (7). But regarding cement augmentation, there are also some concerns about further compromise of the femoral head circulation by cement (8). Therefore, little is available to avoid fixation failure following hip fracture, such as proper patient selection, optimal reduction of the fracture and proper positioning of the fixation devices.

Although significant differences were demonstrated between different regions of proximal femur by using quantitative $\mathrm{CT}$, the difference between DXA measurements of different regions of proximal femur is not as much as expected(4). The reason for this may be due to $2 \mathrm{D}$ nature of the measurement by DXA, and effect of neighboring cortical bone on $\mathrm{x}$-ray absorption. In our study, we found a positive correlation of PC-BMD with BMD of other parts of proximal femur of uninvolved side as expected. Highest correlation was found to be between uninvolved side femoral neck BMD with PC-BMD, at both sexes. This may be attributed to the close proximity of these two anatomical areas. Since force-deflection characteristics of femoral head (cancellous) and femoral neck (cortical and cancellous) and biomechanical influences (head: compression, neck: compression-distraction) are not unique, this relation can be totally sporadical. To confirm these findings, densitometric and biomechanical evaluation of both areas should be done. Highest correlation of PC-BMD and neck BMD correlation was also observed in both osteoporotic and osteopenic cases, which also confirms the results.

DXA evaluation for osteoporosis diagnosis has some issues such as different BMD results from different parts of the body such as hip or spine(9). Also it was shown that there may be significant right- left differences in hip DXA evaluation. Mounach et al. reported a difference range of 0.001-0.021 $\mathrm{g} / \mathrm{cm} 2 \mathrm{BMD}$ changes and 0.007-0.045 T-score difference between two hip measurements (10). Since difference between DXA measurements exceeded this possible right-left difference range, this factor may be negligible, in terms of BMD correlation between different parts of the same hip.

There are some weak sides in this study. First drawback is the method of radiological evaluation. Numerous methods were described for evaluation of bone mineral density and bone microarchitecture such as quantitative computerized tomography, ultrasound and 3 Tesla high resolution MRI besides DXA.
Although DXA is not accepted as a gold standard measurement tool for the evaluation of bone mineral status anymore, due to readily availability and comparably standardized evaluation properties, we conclude that DXA method is still valuable and remain as a useful tool for diagnosis, decision making and follow up of osteoporotic patients. Other weak sides of study can be summarized as the lack of normal cases (non-osteoporotic-penic) for comparison of PC-BMD and other parts of proximal femur. Also absence of non- fractured osteoporotic femoral heads, since fracture may alter bone mineral density of femoral head.

\section{CONCLUSION}

Bone mineral density of the femoral head primary compressive trabeculation area, which is the primary anchorage point for fixation devices, is strongly correlated with uninvolved side femoral neck bone mineral density. Since osteoporosis is a risk factor for loss of fixation at femoral neck fractures, preoperative evaluation of uninvolved side femoral neck BMD is valuable to estimate BMD status of the femoral head. Further research including biomechanical studies and outcome studies regarding failure incidence of patients undergoing fracture fixation with low PC-BMD values are needed for clinical use of this value.

\section{Conflict of Interest}

No conflict of interest was declared by the authors.

\section{REFERENCES}

1. Sjostedt A, Zetterberg C, Hansson T, Hult E, Ekstrom L. Bone mineral content and fixation strength of femoral neck fractures. A cadaver study. Acta Orthop Scand. 1994;65:161-5.

2. Dalen $N$, Jakobsson $B$. Factors influencing the incidence of reoperation after femoral neck fractures. Int Orthop. 1985;9:235-7.

3. Bonnaire FA, Buitrago-Tellez C, Schmal H, Götze B, Weber AT. Correlation of bone density and geometric parameter to mechanical strength of the femoral neck. Injury 2002;33(Suppl 3):47-53.

4. Bonnaire $F$, Zenker $H$, Lill $C$, Weber AT, Linke B. Treatment strategies for proximal femur fractures in osteoporotic patients. Osteoporosis int. 2005;16:93-102.

5. Hedström M. Are patients with a nonunion after a femoral neck fracture more osteoporotic than others? BMD measurement before the choice of treatment? Acta Orthop Scand. 2004 Feb;75(1):50-2.

6. Jenny J, Rapp E, Cordey J. Type of screw does not influence holding power in the femoral head. Acta Orthop Scand. 1999;70:435-8.

7. Fensky F, Nüchtern JV, Kolb JP, Huber $S$ et al. Cement augmentation of the proximal femoral nail antirotation for the treatment of osteoporotic pertrochanteric fractures--a biomechanical cadaver study. Injury. 2013;44:802-7.

8. Claes L, Becker C, Simnacher M, Hoellen I. Improvement in the primary stability of the dynamic hip screw osteosynthsis in unstable, pertrochanteric femoral femoral fractures of osteoporotic bones by a new glass inomer cement. Unfallchirurg. 1995;98:118-23.

9. Hamdy R, Kiebzak GM, Seier $\quad$, Watts NB The prevalence of significant left- right differences in hip bone mineral density. Osteoporos Int. 2006;17:1772-80.

10. Mounach A, Rezqi A, Ghozlani I, Achemlal L, Bezza A, El Maghraoui A. Prevalence and Risk Factors of Discordance between Left-and RightHip Bone Mineral Density Using DXA. ISRN Rheumatol. 2012;ID:617535. doi: $10.5402 / 2012 / 617535$. 